\title{
Intra Abdominal Fibromatosis Mimicking GIST; A Case Report and Review of the Literature
}

\author{
Safi khuri ${ }^{1 *}$, Yuram Kluger ${ }^{1,2}$ and Bishara Bishara ${ }^{1,3}$ \\ ${ }^{1}$ Department of General Surgery, Rambam Health Care Campus, Israel \\ ${ }^{2}$ Hepato-Pancreatico-Biliary and Surgical Oncology unit, Israel \\ ${ }^{3}$ Minimally invasive surgery unit, Israel
}

Submission: June 06, 2017; Published: August 10, 2017

*Corresponding author: Safi Khuri, Department Of General Surgery, Rambam Health Care Campus, $8^{\text {th }}$ haalia St, Haifa, Israel, Tel: 97247772516 ; Fax: 97248543273; Email: s_khuri@rambam.health.gov.il

Abstract

A 22 years old female patient, presented with a painless abdominal mass of 2 weeks duration, without other symptoms. A mobile, non-tender globular mass was felt at the left upper quadrant. A computed tomography revealed a mass lesion, measuring $8.3 * 8.5 \mathrm{~cm}$, without signs of bowel obstruction. At surgery, a large, $8 \mathrm{~cm}$ mass was found. The mass involved the transverse colon, with its mesocolon and adhered to the greater curvature of the stomach. The mass was excised completely along with a wedge resection of part of the transverse colon and part of the greater curvature. Pathological report revealed an intra-abdominal fibromatosis.

Keywords: GIST; Intra-abdominal fibromatosis; Tyrosine kinase inhibitor; Familial polyposis coli

\section{Introduction}

Intra-abdominal fibromatosis (IAF) is a rare, benign mesenchymal tumor, that can develop at any age. Although rare, it is the most common primary tumor of the mesentry [1]. It can be solitary or multiple with remarkable local aggressiveness. The tumor usually occurs in the mesentry or retroperitoneum, but can occur throughout the gastrointestinal tract [1-3]. IAF is usually secondary to trauma or hormonal stimulation or associated with familial polyposis coli or Gardner's syndrome $[2,4]$. Clinical, radiological and histopathological appearance might mimic the appearance of gastrointestinal stromal tumor (GIST), thus leading to misdiagnosis [5]. Discrimination between the two entities is very important, due to the fact that they have different biological behaviors and different therapeutic strategies; IAF is a benign and with exclusive aggressiveness, usually treated by means of surgical excision with a wide margin of uninvolved tissue, whereas GISTs are usually malignant and may lead to distant metastases, with a significant role of tyrosine kinase inhibitors in addition to surgery in their management $[5,6]$.

As mentioned previously, IAF usually treated by means of surgical excision with a wide margin of uninvolved tissue; however, local recurrence due to incomplete resection have been described in an estimated $16 \%$ of cases, leading to intestinal obstruction and death in 6\% [3]. We report a case of a primary intra-abdominal fibromatosis treated in our department.

\section{Case Report}

A 22 years old, female patient, presented to our emergency department complaining of a painless, palpable abdominal mass at the left upper quadrant of 2 weeks duration. She denied anorexia, weight loss, vomiting or change in bowel habits. Her past medical and surgical histories were unremarkable. She had no family history of malignancy. On admission; her vital signs were within normal limits and on physical examination, a non tender, mobile mass at the left upper quadrant was palpated. Her abdomen was soft, not distended and no other masses were detected. Complete blood count, urinalysis, liver and kidney function tests were all within normal limits. A CT scan of her abdomen and pelvis (Figure 1) revealed a hyper dense lesion with high vascularity, measuring $8.3 \mathrm{~cm} * 8.5 \mathrm{~cm} * 6.6 \mathrm{~cm}$, adhering to the transverse colon and large curvature of the stomach, without evidence of bowel obstruction or intraperitoneal spread. These findings raised a suspicion of gastrointestinal stromal tumor (GIST) at first. The patient was admitted to our department for further work up. Chest CT scan was unremarkable. Endoscopic 
ultrasound (EUS) revealed heterogenous mass lesion, about $86 \mathrm{~mm}$, behind the stomach without involvement of the pancreas. EUS- guided FNA was performed, yielding a paucity of material, not enough for cytologal analysis. At colonoscopy, a submucosal lesion, compressing the lumen externally was identified about $55 \mathrm{~cm}$ from the analverge. Tumor markers -CA19-9, CEA and CA125 were within normal limits. Subsequent exploratory laparotomy revealed a large mass (Figure 2), about $8 \mathrm{~cm}$ in diameter, adhering to the transverse colon with its mesocolon and also to the greater curvature of the stomach, without involvement of the pancreas. The mass was excised with the transverse colon and its mesentry and a wedge resection of the stomach. The patient recovered well from the operation. Pathology report revealed an intra-abdominal fibromatosis (IAF), and the cells were painted positive to Beta-cetenin and negative to CD117 and DOG-1.
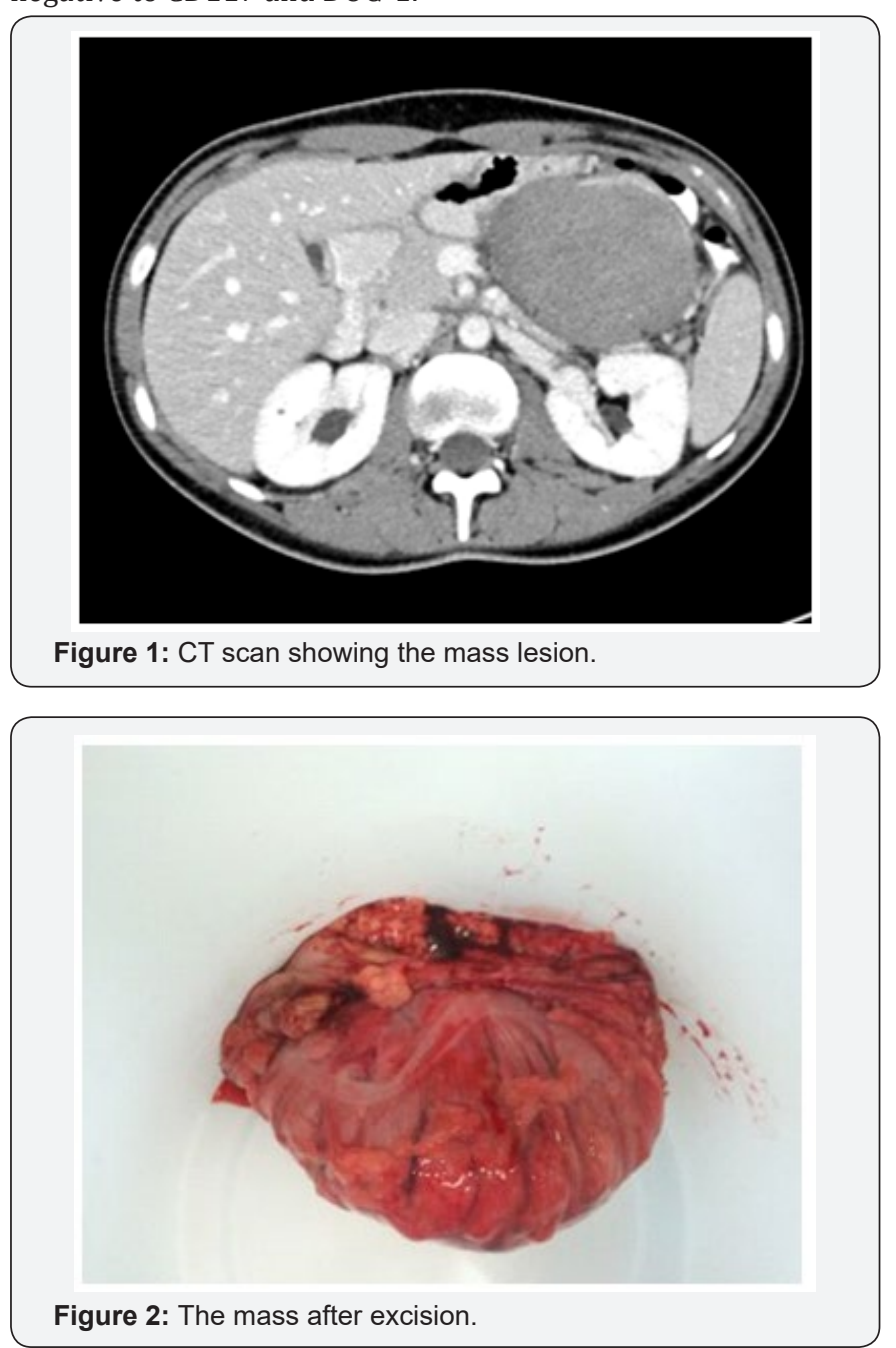

\section{Discussion}

An intra-abdominal fibromatosis (IAF), although known as the most common primary tumor of the mesentry, is a rare benign neoplasm [1]. It is usually secondary to trauma or hormonal stimulation or associated with familial polyposis coli or gardner's syndrome, or it could be primary, which is a rare varient of benign stromal neoplasms of fibroblast myofibroblast origin [2-5]. Diagnosis of IAF is fraught with difficulties, especially when it presents as a tumor adhering to the intestinal wall, thus the diagnosis of GIST may be considered. Comparing to GIST, in which the tumor is usually soft and lobulated with hemorrhage, necrosis or cystification, patients with IAF tend to be younger and the tumor is firm, tan and homogenous. These entities can also be distinguished primarily by their light microscopic and ultrastructural features, but there is a notable overlap in their immunohistochemical profiles (in one study: $88 \%$ of GIST positive to CD117 while $75 \%$ of IAF positive to CD117) [6]. As mentioned above, distinguishing between the two entities is important due to the different treatment protocols and biological behavior. IAF is a low grade neoplasm, treated usually by surgical excision, that may recur, but never metastesies. Recurrence is usually related to incomplete excision. Tamoxifen has been used in the management of a recurrent or unresectable tumor, but it needs to be investigated more. Prognosis of IAF is excellent because it never metastisies.

\section{Conclusion}

A primary Intra-abdominal fibromatosis is a very rare benign tumor, which usually affects the mesentry. The mainstay of treatment is surgical excision, with recurrence mostly related to incomplete excison.

\section{References}

1. Colombo P, Rahal D, Grizzi F, Quagliuolo V, Roncalli M (2005) localized intra-abdominal fibromatosis of the small bowel mimicking a gastrointestinal stromal tumor. World J gastroenterol 11(33): 52265228.

2. Burke AP, Sobin LH, Shekitka KM, Federspiel BH, Helwig EB (1990) Intra-abdominal fibromatosis.A pathologic analysis of 130 tumors with comparison of clinical subgroups. Am J Surg pathol 14(4): 335-341.

3. AL-Nafussi A, Wong NA (2001) Intra-abdominal spindle cell lesions: a review and practical aids to diagnosis. Histopathology 38(5): 387-402.

4. Reitano JJ, Scheinin TM, Hayry P (1986) The desmoid syndrome: new aspects in the cause, pathogenesis and treatment of the desmoid tumor. Am J surg 151(2): 230-237.

5. Kim DH, Goldsmith HS, Quan HS, Huvos AG, Dong-Heup K (1971) Intraabdominal desmoid tumor. Cancer 27(5): 1041-1045.

6. Yantiss RK, Spiro IJ, Compton CC, Rosenberg AE (2000) Gastrointestinal tumor versus intra-abdominal fibromatosis of the bowel wall: A clinically important differential diagnosis. Am J surg pathol 24(7): 947957. 
This work is licensed under Creative Commons Attribution 4.0 Licens DOI: 10.19080/JTMP.2017.01.555567
Your next submission with Juniper Publishers will reach you the below assets

- Quality Editorial service

- Swift Peer Review

- Reprints availability

- E-prints Service

- Manuscript Podcast for convenient understanding

- Global attainment for your research

- Manuscript accessibility in different formats

( Pdf, E-pub, Full Text, Audio)

- Unceasing customer service

Track the below URL for one-step submission https://juniperpublishers.com/online-submission.php 